\title{
Spectrophotometric Assay of Metoclopramide Hydrochloride in Pharmaceutical Preparations via Arsenazo III-Cerium (III) Reaction
}

\author{
Najih H. Shekho \\ Department of Chemistry \\ College of Science \\ University of Mosul \\ Najihshikho@yahoo.com \\ thura.ziad@yahoo.com
}

(Received 15/4/2012 ; Accepted 25/6/2012)

\begin{abstract}
A simple, rapid, accurate and precise spectrophotometric method is proposed for determining metoclopramide - hydrochloride (MCPH) in pure form and in pharmaceutical preparations .The method is based on oxidation - reduction reaction between metoclopramide - hydrochloride and cerium (IV) ion, then the subsequent reaction of cerium (III) and arsenazo III reagent in acidic medium to produce a blue-violet complex which is stable, water-soluble and has a maximum absorption at $654 \mathrm{~nm}$ with a molar absorptivity of $9.36 \times 10^{4} 1 . \mathrm{mol}^{-1} . \mathrm{cm}^{-1}$ and Sandell's sensitivity of $0.0038 \mu \mathrm{g} . \mathrm{cm}^{-2}$. Beer's law is obeyed in concentration range from 1-30 $\mu \mathrm{g}$ metoclopramide - hydrochloride in final volume of $25 \mathrm{ml},(0.04-1.2) \mathrm{ppm}$ with a relative standard deviation $(\mathrm{RSD})( \pm 1.80 \%$ $\pm 3.98 \%$ ) and the limit of detection (LOD) is $0.0095 \mu \mathrm{g} / \mathrm{ml}$ and the limit of quantitation (LOQ) is $0.0317 \mu \mathrm{g} / \mathrm{ml}$. The method is suitable for the determination of metoclopramide hydrochloride in the presence of other ingredients that are usually present in dosage forms and the recoveries are obtained in the range of 97.6-101.0\%. The proposed method has been applied successfully to the determination of the intended compound in its pharmaceutical preparations ( tablet and injection).
\end{abstract}

Keywords: Metoclopramide hydrochloride, spectrophotometry, arsenazo III.

\section{القدير الاليف الميتوكلوسراميد هيدوكلوربدفي المستحضرات الصيدلانية اعتمادا عل فالى

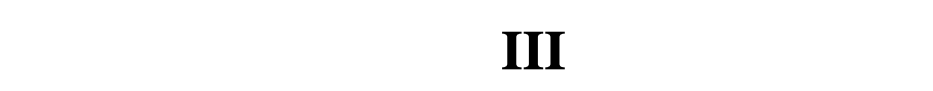

\section{المالغص}

مق اقتراحطريقةطفية بسيطة وسريعة و دقيقة ومتوافقة لقدير الميتوكلوبرلميد هيدروكلوريد ب ششكله

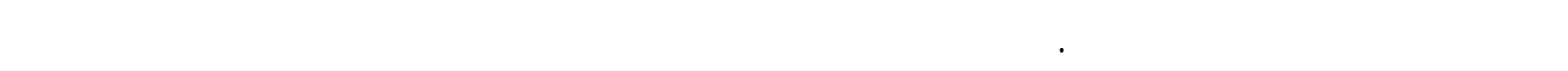

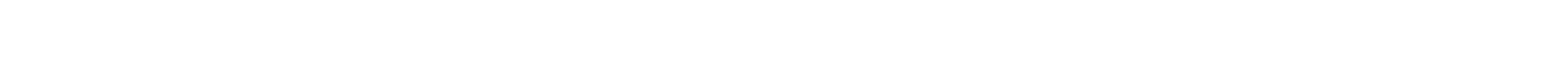

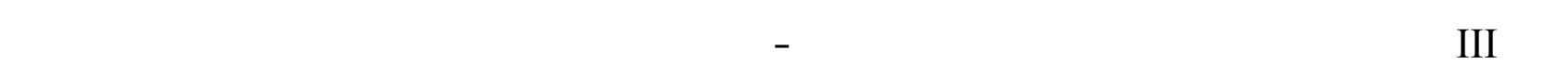






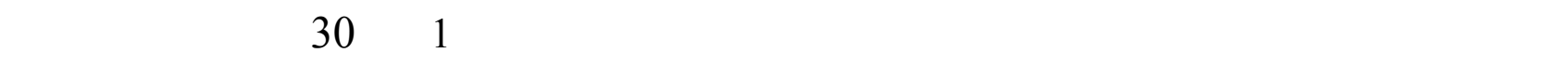
الميتوكلوبراميد هيدروكلوريد في حهم نهائي 25 ململتر (0.04 - 1.2 جزء بالمليون) وكان الانحرف القياف القيلسي

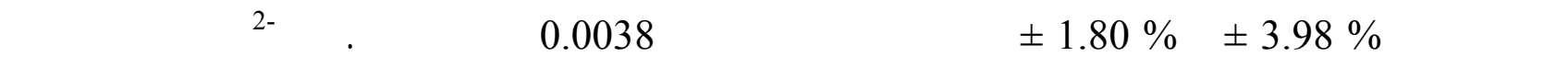

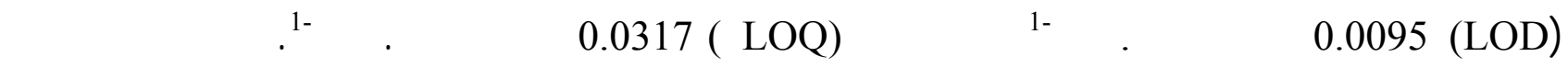

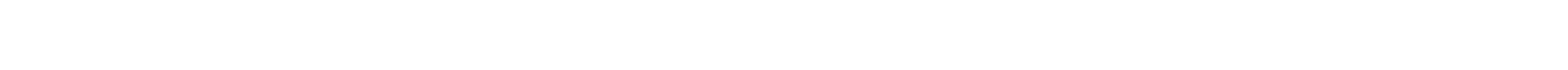

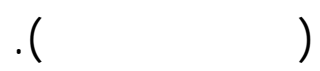

الكاملت الدالة : الميتوكلوبرلميد هيدروكلوريد، الطيفية، اسسن ازو III.

\section{INTRODUCTION}

Metoclopramide-hydrochloride (MCPH) is a white or almost white, odorless, crystalline powder (m.p. about $185 \mathrm{C}^{\mathrm{o}}$ ), very soluble in water, alcohol and partially insoluble in ether.

Chemically (MCPH) is: 4-amino-5-chloro-N-(2-diethylaminoethyl)-2methoxybenzamide monohydrochloride monohydrate (British Pharmacopoeia, 2008).

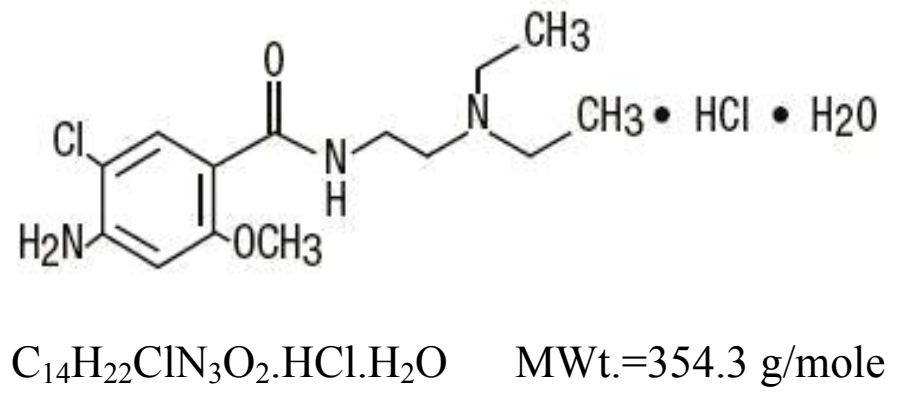

Metoclopramide was used as a treatment of nausea and vomiting in association with migraine and severe headache. In this setting, the combination of metoclopramide with an analgesic proved to be very efficacious with a short delay of action. The drug was used for the control of sickness due to radiation therapy and chemotherapy, and for the prevention and treatment of postoperative nausea and vomiting (PONV). Metoclopramide also has a gastrointestinal prokinetic effect through cholinergic stimulation.This effect consists of an increased tension in the lower esophageal sphincter and the gastric fundus, an increase in gastric and small intestinal motility, and a relaxation of the pylorus and duodenum during contraction of the stomach. The gastro-kinetic effect is mediated by an antagonism at the $\mathrm{D}_{2}$ and $5-\mathrm{HT}_{3}$ receptors and by activation of the $5-\mathrm{HT}_{4}$ receptor ( Donnerer, 2003).

Many analytical methods have been employed for the determination of $\mathrm{MCPH}$, such as: fluorimetry (Attia and Aboaly, 2010), chromatography (Avula et al., 2011), capillary electrophoresis (Chang et al., 2000), liquid chromatography -mass spectroscopy (LC-MS) (Maquille and Jiwan 2009), potentiometry (Faridbod et al., 2009), voltammetry (Wang et al., 2001), fast stripping continuous cyclic voltammetry (Norouzi et al., 2005), 
square wave anodic stripping voltammetry (Farghaly et al., 2005) and $\mathrm{H}^{1} \mathrm{NMR}$ spectroscopy (Hanna and Lau-Cam, 1991).

The chromatographic methods are a lot cost, they are consuming of time and limiting of application and also the flow-injection chemiluminescent are often typically less sensitive and have their own intrinsic disadvantages such as technical complexity or require an expensive instrumentation (Al-Arfaj, 2004).

Spectrophotometry is the technique of choice even today due to its inherent simplicity. In the literature, many spectrophotometric procedures have been applied for the determination of MCPH using different reagents including o-phenanthroline or bipyridyl in the presence of Fe III as an oxidizing agent (Amin and Ragab, 2003); other spectrophotometric methods based on diazotization and coupling with different reagent such as: dibenzoylmethane (Revanasiddappa and Manju, 2001), benzoylacetone (Omran, 2005), aniline (Shah et al., 2005), $\beta$-naphthol (Patel et al., 2006), impramine hydrochloride (Revanasiddappa and Veena, 2006) and 2,4-dihydroxy acetophenone (Khalil, 2010).

Other spectrophotometric methods have been reported such as: ion association complex formation (Abdel-Gawad and El-Guindi, 1995), charge-transfer complex formation (Al-Gabsha et al., 2004), or through the formation of the Schiff's base with pdimethylamino-cinnamaldehyde (Moussa, 2000).

The aim of the present work is to develop a simple, sensitive, specific spectrophotometric method for the determination of $\mathrm{MCPH}$ in bulk as well as pharmaceutical formulation.

\section{Apparatus}

\section{EXPERIMENTAL}

All spectral and absorbance measurements were performed on double-beam Shimadzu UV-Visible-160 recording spectrophotometer with $1.0 \mathrm{~cm}$ matched glass cells. $\mathrm{pH}$ measurements were preformed using HANNA $301 \mathrm{pH}$ meter.

\section{Reagents}

All chemicals used were of analytical grade reagents.

Standard solution of MCPH (100 $\mathrm{\mu g} / \mathrm{ml})$. It was prepared by dissolving $0.0100 \mathrm{~g}$ of $\mathrm{MCPH}$ (N.D.I) in distilled water and the volume was completed to $100 \mathrm{ml}$ with distilled water in a volumetric flask. The solution was then transferred to a dark bottle and is stable for at least one month.

Working solution of MCPH $(25 \mu \mathrm{g} / \mathrm{ml})$. It was prepared by the appropriate dilution of the stock solution with distilled water.

Ammonium ceric sulphate dihydrate [cerium(IV)ion solution],(4x10 $\left.{ }^{-4} \mathbf{M}\right)$. This solution has been prepared by dissolving $0.0253 \mathrm{~g}$ of ammonium ceric sulphate dihydrate in sulphuric acid $(0.05 \mathrm{~N})$ and the volume was completed to $100 \mathrm{ml}$ with sulphuric acid $(0.05 \mathrm{~N})$ in a volumetric flask.

Arsenazo III reagent solution, $\left(6 \times 10^{-4} \mathbf{M}\right)$. It was prepared by dissolving $0.0535 \mathrm{~g}$ of Arsenazo III. $4 \mathrm{H}_{2} \mathrm{O}$ (HIMEDIA) in $100 \mathrm{ml}$ distilled water in a volumetric flask. 
Sulphuric acid solution,(0.05N).This solution is prepared by dilution of $1.4 \mathrm{ml}$ of the concentrated sulphuric acid $(35.5 \mathrm{~N})$ solution to $1000 \mathrm{ml}$ with distilled water in a volumetric flask.

Sodium hydroxide solution (1M).This solution is prepared by appropriate dilution of the concentrated volumetric (Fluka) solution with distilled water to $1000 \mathrm{ml}$ in a volumetric flask and then transferred to a plastic bottle.

Sodium hydroxide solution ( $\mathbf{0 . 0 1 M})$. This solution is prepared by dilution of $1.0 \mathrm{ml}$ of the concentrated $\mathrm{NaOH}(1 \mathrm{M})$ solution to $100 \mathrm{ml}$ with distilled water in a volumetric flask.

\section{Recommended procedure and calibration curve}

An aliquot of standard solution (1-50) $\mu \mathrm{g}$ of $\mathrm{MCPH}$ was transferred into a series of 25$\mathrm{ml}$ volumetric flasks. To each flask, $2.5 \mathrm{ml}$ of sodium hydroxide $(0.01 \mathrm{M})$ solution and 0.5 $\mathrm{ml}$ ammonium ceric sulphate dihydrate solution were added. The reaction mixture was allowed to stand for 20 min after mixing thoroughly. A $0.7 \mathrm{ml}$ of arsenazo III was added and the contents were diluted to the mark with distilled water and mixed well. The absorbance of the formed coloure (blue-violet) was measured at $654 \mathrm{~nm}$ against the corresponding reagent blank. A linear calibration graph was obtained over the concentration range of (1-30) $\mu \mathrm{g}$ of $\mathrm{MCPH} / 25 \mathrm{ml},(0.04-1.2) \mathrm{ppm}$. Higher concentrations show a negative deviation from Beer's law (Fig.1). The apparent molar absorptivity has been found to be $9.36 \times 10^{4} 1 . \mathrm{mol}^{-1} . \mathrm{cm}^{-1}$ and Sandell's sensitivity is $0.0038 \mu \mathrm{g} . \mathrm{cm}^{-2}$ and the limit of detection (LOD) is $0.0095 \mu \mathrm{g} / \mathrm{ml}$ and the limit of quantitation (LOQ) is $0.0317 \mu \mathrm{g} / \mathrm{ml}$.

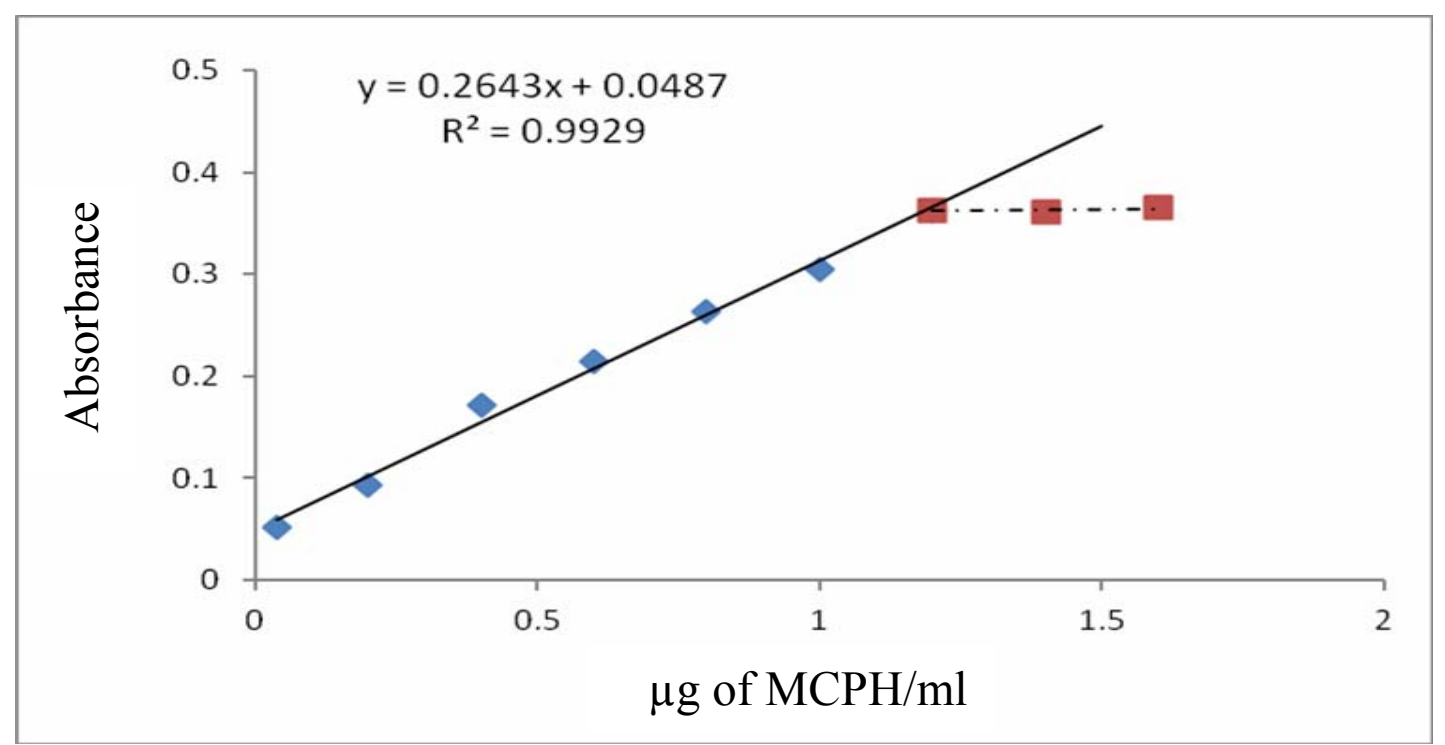

Fig 1: Calibration graph for MCPH determination 


\section{Procedure for dosage forms}

For tablets: at least ten tablets ( $5 \mathrm{mg} \mathrm{MCPH} /$ tablet ) of the drug were weighed, powdered and mixed well. A portion equivalent to $0.01 \mathrm{~g}$ of $\mathrm{MCPH}$ was weighed and dissolved in $100 \mathrm{ml}$ of distilled water, shaken well, filtered and diluted with water to $100 \mathrm{ml}$ in a volumetric flask. An aliquot of the diluted drug solution was then treated as done in a recommended procedure.

For injection: the content of the container of MCPH injection $(10 \mathrm{mg} \mathrm{MCPH} / 2 \mathrm{ml})$ was mixed well and transferred into $100 \mathrm{ml}$ volumetric flask and completed to the mark with distilled water. An aliquot of the diluted drug solution was then treated as done in recommended procedure.

\section{RESULTS AND DISCUSSION}

\section{The Principle of colour reaction}

Under the reaction conditions, metoclopramide hydrochloride $(\mathrm{MCPH})$ was treated with ammonium ceric sulphate dihydrate in acidic medium, which undergoes oxidation reduction reaction to give Ce (III) ions. The cerium III formed was quantitatively and rapidly converted into the stable arsenazo III - Ce (III) coulered complex which exhibited absorption maxima at $654 \mathrm{~nm}$ against reagent blank solution. The intensity of the formed complex has been found to be proportional to the amount of MCPH originally present in solution.

\section{Optimization of variables}

The effect of various parameters on the absorption intensity of the coloured complex is studied and the reaction conditions have been optimized. The preliminary investigation showed that the complex formed have a maximum absorption at $654 \mathrm{~nm}$ against reagent blank.

\section{Effect of pH}

The effect of $\mathrm{pH}$ on the intensity of the coloured complex is examined. Different volumes $(0.5-3.5 \mathrm{ml})$ of $0.01 \mathrm{M}$ sodium hydroxide are added to an aliquot of solution containing $25 \mu \mathrm{g} \mathrm{MCPH} / 25 \mathrm{ml}$. The absorbances are read against the reagent blank. The results are shown in Table 1

Table 1: Effect of pH on absorbance.

\begin{tabular}{|c|c|c|}
\hline ml of 0.01 M NaOH & Absorbance & Final pH \\
\hline 0 & 0.065 & 2.91 \\
\hline 0.5 & 0.192 & 2.96 \\
\hline 1.0 & 0.273 & 3.03 \\
\hline 1.5 & 0.284 & 3.13 \\
\hline 2.0 & 0.298 & 3.23 \\
\hline 2.5 & 0.310 & 3.36 \\
\hline 3.0 & 0.288 & 3.58 \\
\hline 3.5 & 0.278 & 4.07 \\
\hline
\end{tabular}


The results shown in Table 1 indicate that the $\mathrm{pH}$ of $3.36(\mathrm{pH} \approx 3.4)$ is considered optimum. A pH 3.4 is selected for subsequent investigation as it gives maximum absorbance for the coloured product. Four buffer solutions of $\mathrm{pH} 3.4$ with different compositions have: tartaric acid- $\mathrm{NaOH}\left(\mathrm{B}_{1}\right)$, citric acid- $\mathrm{NaOH}\left(\mathrm{B}_{2}\right), \mathrm{KH}$ Phthalate- $\mathrm{HCl}\left(\mathrm{B}_{3}\right)$, and glycine- $\mathrm{HCl}$ $\left(B_{4}\right)$ ( Perrin and Dempsey, 1974).The results indicate that all types of buffer solutions decrease the intensity and stability of absorption of the coloured complex, so the use of buffer solutions is not recommended. A $2.5 \mathrm{ml}$ of $0.01 \mathrm{M} \mathrm{NaOH}$ solution has been recommended for subsequent experiments.

\section{Effect of oxidizing agent [cerium(IV) ion] amount}

Different amounts of cerium(IV) ion solution are added to $2.5-30 \mu \mathrm{g}$ of $\mathrm{MCPH} / 25 \mathrm{ml}$ and the optimum amount which gives higher intensity of coloured complex and higher value of correlation coefficient (Table 2) has been selected

Table 2: Effect of ceric ion amount on absorbance.

\begin{tabular}{|c|c|c|c|c|c|c|c|c|}
\hline \multirow{2}{*}{$\begin{array}{c}\text { ml of } 4 \times 10^{-4} \\
M \text { cerium(IV) } \\
\text { ion solution }\end{array}$} & \multicolumn{6}{|c|}{ Absorbance/pg MCPH in $25 \mathrm{ml}$} & \multirow{2}{*}{$\begin{array}{c}\text { ml of } \\
\text { NaOH } \\
(0.01 M)^{*}\end{array}$} & \multirow{2}{*}{$\mathbf{R}^{2}$} \\
\hline & 2.5 & 5.0 & 10.0 & 20 & 25 & 30 & & \\
\hline 0.2 & 0.063 & 0.096 & 0.123 & 0.135 & 0.123 & 0.137 & 1.0 & 0.7251 \\
\hline 0.5 & 0.082 & 0.010 & 0.150 & 0.267 & 0.322 & 0.363 & 2.5 & 0.9976 \\
\hline 0.7 & 0.08 & 0.111 & 0.140 & 0.287 & 0.339 & 0.404 & 3.5 & 0.9927 \\
\hline 1.0 & 0.101 & 0.106 & 0.164 & 0.300 & 0.356 & 0.427 & 5 & 0.9941 \\
\hline 1.5 & 0.102 & 0.135 & 0.208 & 0.334 & 0.379 & 0.449 & 7.5 & 0.9975 \\
\hline
\end{tabular}

* Used for $\mathrm{pH}$ adjustment to 3.4

The results shown in Table 2 indicate that the volume of $0.5 \mathrm{ml}$ of $4 \times 10^{-4} \mathrm{M}$ cerium (IV) ion solution gives good correlation coefficient and the lower blank value(0.106) compared with $1.5 \mathrm{ml}$ of the oxidant gives (0.289) absorbance value.

\section{Effect of reaction time}

The effect of time needed for the complete reduction of cerium (IV) to cerium (III) ion is studied by standing of the solutions after adding cerium (IV) ion solutions for different times, then the reagent is added and the absorbance are measured against the reagent blank and the results indicate that a complete reduction of cerium (IV) ion occurred after 20 minutes. Therefore, the time ( 20 minutes) is recommended for the subsequent experiments.

\section{Effect of arsenazo III reagent amount}

The effect of the amount of arsenazo III reagent on the maximum formation of the coloured complex is investigated for $2.5-30 \mu \mathrm{g}$ of $\mathrm{MCPH} / 25 \mathrm{ml}$. The results are shown in Table 3. 
Table 3: Effect of arsenazo III reagent amount on absorbance.

\begin{tabular}{|c|c|c|c|c|c|c|c|c|}
\hline \multirow{2}{*}{ 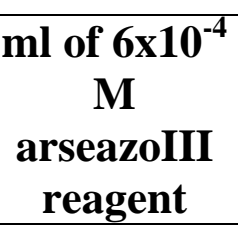 } & \multicolumn{6}{|c|}{ Absorbance/pg MCPH in 25ml } & \multirow[b]{2}{*}{ Blank } & \multirow{2}{*}{$\mathbf{R}^{2}$} \\
\hline & 2.5 & 5 & 10 & 20 & 25 & 30 & & \\
\hline 0.5 & 0.07 & 0.089 & 0.138 & 0.245 & 0.299 & 0.308 & 0.085 & 0.9846 \\
\hline 0.7 & 0.08 & 0.09 & 0.160 & 0.265 & 0.316 & 0.363 & 0.105 & 0.9969 \\
\hline 1.0 & 0.07 & 0.085 & 0.150 & 0.256 & 0.302 & 0.339 & 0.116 & 0.9953 \\
\hline 1.5 & 0.054 & 0.080 & 0.138 & 0.236 & 0.281 & 0.318 & 0.122 & 0.9967 \\
\hline 2.0 & 0.050 & 0.076 & 0.120 & 0.221 & 0.256 & 0.292 & 0.140 & 0.9962 \\
\hline
\end{tabular}

The results shown in Table 3 indicate that $0.7 \mathrm{ml}$ of arsenazo III reagent solution gives the good sensitivity and good value of correlation coefficient, therefore it has been selected for subsequent experiments.

\section{Effect of surfactant}

The effect of surfactant was studied by the addition of $3 \mathrm{ml}$ of various types of surfactant (positive, negative and neutral charged) to the medium of reaction with different orders of addition. The results are shown in Table 4.

Table 4: Effect of surfactants and the order of additions.

\begin{tabular}{|c|c|c|c|c|}
\hline \multirow{2}{*}{$\begin{array}{c}\text { Surfactant } \\
\text { solution* }\end{array}$} & \multicolumn{4}{|c|}{ Absorbance $* * / o r d e r * * *$ of addition } \\
\hline & $\mathbf{I}$ & II & III & IV \\
\hline $\begin{array}{c}\text { CTAB } \\
1 \times 10^{-3} \mathrm{M} \\
\end{array}$ & turbid & turbid & turbid & turbid \\
\hline $\begin{array}{c}\text { SDS } \\
1 \times 10^{-3} \mathrm{M}\end{array}$ & 0.294 & 0.263 & 0.263 & 0.226 \\
\hline $\begin{array}{c}\text { Triton X-100 } \\
1 \% \mathrm{v} / \mathrm{v}\end{array}$ & 0.312 & 0.292 & 0.230 & 0.277 \\
\hline \multicolumn{5}{|c|}{$\begin{array}{l}\text { *TAB :Cetyltrimethylamoniumbromide (positively charged) } \\
\text { SDS :Sodium dodecyl sulphate (negatively charged) } \\
\text { TritonX-100: Iso-Octylphenoxypolyethoxyethanol (neutral) }\end{array}$} \\
\hline \multicolumn{5}{|c|}{ ** Absorbance without surfactant $=0.326$} \\
\hline \multicolumn{5}{|c|}{$\begin{array}{l}\text { *** } \text { I. } \mathrm{MCPH}+\mathrm{Ce}^{+4}+\mathrm{NaOH}+\text { Reagent }(\mathrm{AzIII})+\operatorname{Surfactant}(\mathrm{S}) \\
\text { II. } \mathrm{MCPH}+\mathrm{Ce}^{+4}+\mathrm{NaOH}+\mathrm{S}+\mathrm{AzIII}\end{array}$} \\
\hline $\begin{array}{lr}\text { III. } & \text { MCP } \\
\text { IV. } & \text { MC }\end{array}$ & $\begin{array}{l}+3+\mathrm{Sa} \\
\mathrm{Ce}^{+4}+\mathrm{N}\end{array}$ & & & \\
\hline
\end{tabular}

The results in Table 4 indicate that all types of surfactants solutions decrease the intensity of absorption of the coloured complex, so that the use of surfactants solutions is not recommended. 


\section{Effect of time}

The effect of time on the development and stability of coloured complex for different amounts of MCPH is investigated under the optimum experimental conditions established. Complete colour formation occurs immediately after all reaction mixtures are added and the absorbance of the complex remains constant for at least 60 minutes (Table 5)

Table 5: Effect of time on the absorbance of complex.

\begin{tabular}{|c|c|c|c|c|c|c|c|c|c|c|}
\hline Hg of & \multicolumn{10}{|c|}{ Absorbance*/ min } \\
\cline { 2 - 11 } MCPH & 0 & 5 & 10 & 15 & 20 & 25 & 30 & 40 & 50 & 60 \\
\hline 5 & 0.071 & 0.073 & 0.073 & 0.074 & 0.073 & 0.072 & 0.073 & 0.072 & 0.071 & 0.071 \\
\hline 25 & 0.326 & 0.325 & 0.323 & 0.321 & 0.320 & 0.319 & 0.315 & 0.311 & 0.308 & 0.308 \\
\hline
\end{tabular}

* After 20 minutes reaction time of $\mathrm{MCPH}$ with $\mathrm{Ce}^{+4}$ ion before addition of reagent

The results shown in Table 5 indicate that the stability period is sufficient to allow several measurements to be performed sequentially.

\section{Absorption spectra}

Absorption spectra of the coloured complex formed from the reaction between cerium III ion with arsenazo III reagent in acidic medium against its corresponding reagent blank show maximum absorption at $654 \mathrm{~nm}$ in contrast to the arsenazo III reagent blank which shows a weak absorption at the same wavelength (Fig.2).

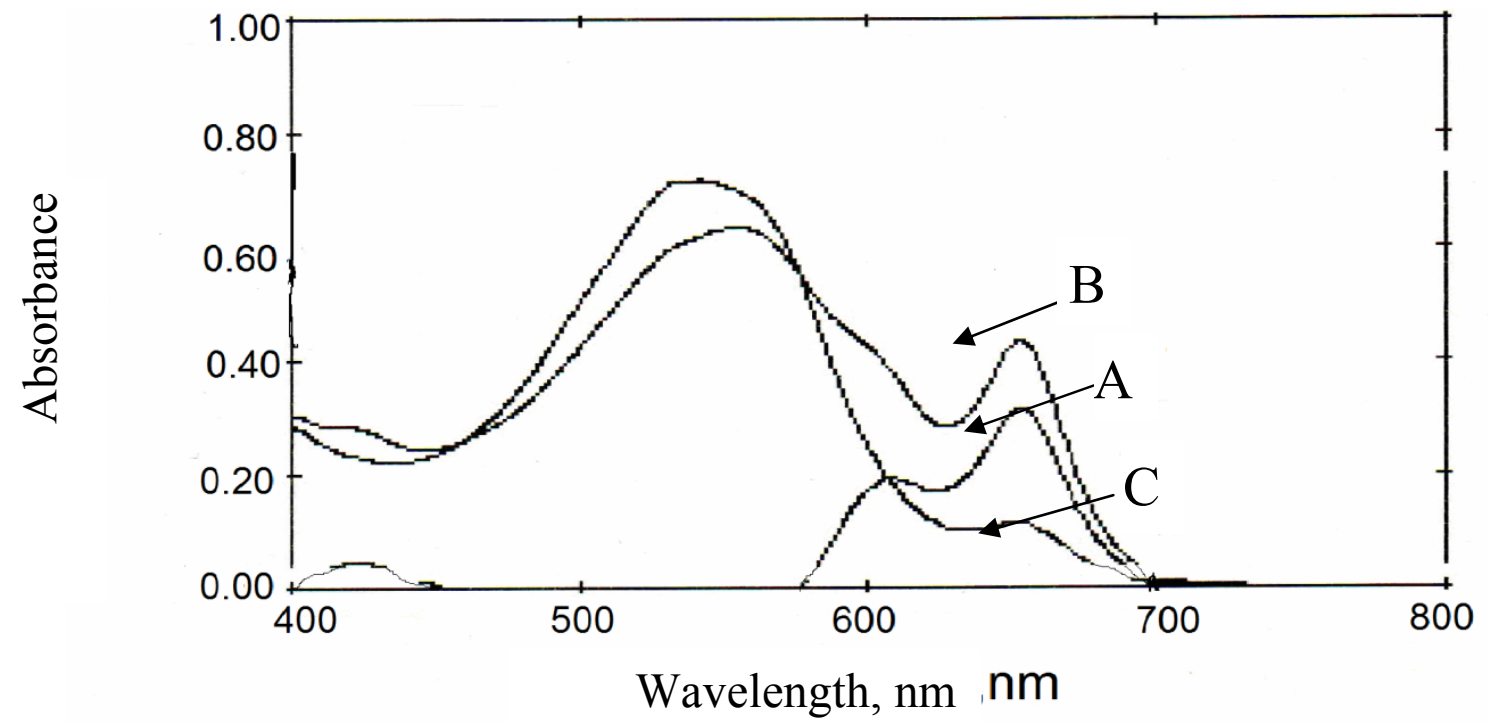

Fig. 2: Absorption spectra of $25 \mu \mathrm{M} \mathrm{MCPH} / 25 \mathrm{ml}$ treated according to the optimum conditions and measured against (A) blank ,(B) distilled water and (C) blank measured against distilled water.

\section{Accuracy and precision}

To check the accuracy and precision, $\mathrm{MCPH}$ was determined at three different concentrations. The results are shown in Table 6 indicate that the method is satisfactory. 
Table 6: Accuracy and precision of the proposed method.

\begin{tabular}{|c|c|c|}
\hline $\begin{array}{c}\text { Amount of MCPH } \\
\text { taken, } \boldsymbol{\mu g} .\end{array}$ & Recovery \% * & Relative standard deviation, \% * \\
\hline 5 & 99.8 & \pm 3.98 \\
\hline 10 & 98.6 & \pm 2.38 \\
\hline 25 & 100.5 & \pm 1.80 \\
\hline
\end{tabular}

*Average of five determinations.

\section{Nature of the reaction between MCPH and cerium IV ion}

Job's method has been used in the determination of the reaction ratio of MCPH with cerium(IV) ion. The obtained results in (Fig.3) showed that a1:1 MCPH to cerium IV ion ratio is obtained.



Fig. 3 : Job's plot for MCPH-Cerium(IV) ion

The probable mechanism of the reaction may be according to the following :<smiles>CCN(CC)CCNC(=O)c1cc(Cl)c(N)cc1OC</smiles><smiles>CCN(CC)CCNC(=O)c1cc(OC)c(NNc2cc(OC)c(C(=O)NCCN(CC)CC)cc2Cl)cc1Cl</smiles>

\section{Nature of arsenazo III-cerium (III) ion complex}

The stoichiometry of the reaction is investigated using the Job's and mole ratio methods (Delevie,1997) under the optimized conditions. The obtained results showed that a 
1:1 arsenazo III to cerium (III) ion ratio is obtained, this result is identical with that in the literature (Sandell and Onishi, 1978)

The probable mechanism of the reaction might be as the following:

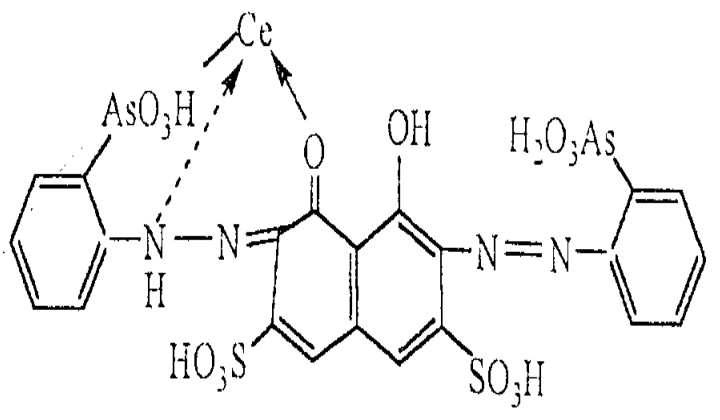

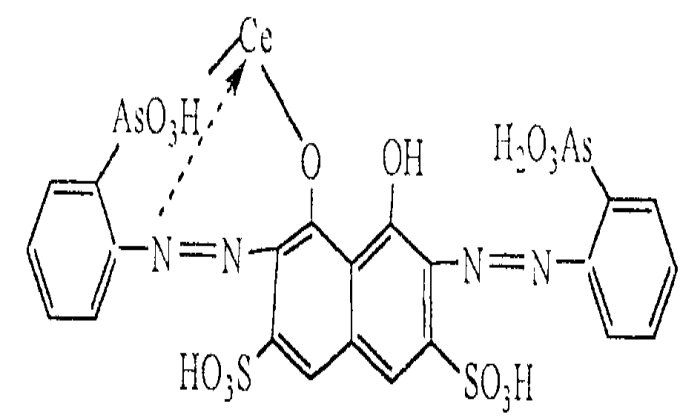

$\underline{\text { or }}$

\section{Effect of interferences}

In order to test the efficiency and selectivity of the proposed method, the effect of some foreign substances (e.g., acacia, glucose, lactose, sorbitol, and starch) that usually present in dosage forms were studied by adding different amounts of foreign substances to $25 \mu \mathrm{g}$ $\mathrm{MCPH} / 25 \mathrm{ml}$. It was observed that the studied foreign species did not interfere in the present method (Table 7).

Table 7: Effect of additives and excipients on the determination of $25 \mu \mathrm{g}$ of MCPH $/ 25 \mathrm{ml}$.

\begin{tabular}{|c|c|c|c|}
\hline \multirow{2}{*}{ Interferences } & \multicolumn{3}{|c|}{ Recovery(\%) of $\mathbf{M C P H} / \mathbf{p p m}$ of interfere added } \\
\cline { 2 - 4 } & $\mathbf{1 0 0}$ & $\mathbf{5 0 0}$ & $\mathbf{1 0 0 0}$ \\
\hline Acacia & 99.3 & 96.0 & 95.0 \\
\hline Glucose & 101.3 & 99.3 & 101.6 \\
\hline Lactose & 103.2 & 102.1 & 99.3 \\
\hline Sorbitol & 102.8 & 96.7 & 96.0 \\
\hline Starch & 101.9 & 101.6 & 103.2 \\
\hline
\end{tabular}

\section{Application of the method}

The proposed method was successfully applied to the determination of MCPH in its pharmaceutical preparations (tablet and injection). The results which are shown in Table 8 indicate that good recoveries were obtained. 
Table 8: Analytical applications.

\begin{tabular}{|c|c|c|c|c|}
\hline \multirow{2}{*}{$\begin{array}{c}\text { MCPH } \\
\text { Amount } \\
\boldsymbol{\mu g} / \mathbf{2 5} \mathbf{~ m l}\end{array}$} & $\begin{array}{c}\text { Meclodin } \\
\text { (5mg MCPH } \\
\text { / tablet) NDI- } \\
\text { Iraq }\end{array}$ & $\begin{array}{c}\text { Mecovery(\%) of MCPH* } \\
\text { (5mg MCPH } \\
\text { / tablet) SDI-Iraq }\end{array}$ & $\begin{array}{c}\text { MCPH } \\
\text { injection } \\
(\mathbf{1 0 ~ m g / 1 m l ) ~} \\
\text { Germany }\end{array}$ & $\begin{array}{c}\text { MCPH } \\
\text { injection } \\
(\mathbf{1 0} \text { mg/1ml) } \\
\text { China }\end{array}$ \\
\hline 10 & 98.8 & 101.0 & 100.0 & 98.8 \\
\hline 15 & 100.0 & 99.5 & 98.3 & 100.0 \\
\hline 25 & 98.4 & 97.6 & 100.0 & 100.56 \\
\hline
\end{tabular}

*Average of three determinations.

The performance of the proposed method was a ssessed by calculating the student's ttest and F-test (Christian, 2004) compared with the literature method (Khalil, 2010). The results in Table 9 show that the calculated values of t-test and F-test did not exceed the theoretical values at the $95 \%$ confidence indicating that there is no significant difference between the proposed method and the literature method.

Table 9: Determination of MCPH in pharmaceutical preparations.

\begin{tabular}{|c|c|c|c|c|c|}
\hline & \multirow{2}{*}{ DCPH } \\
\cline { 3 - 6 } & amount, $\boldsymbol{\mu g}$ & $\begin{array}{c}\text { Present } \\
\text { method }\end{array}$ & $\begin{array}{c}\text { Literature method } \\
\text { (Khalil, 2010) }\end{array}$ & t-exp & F-exp \\
\hline $\begin{array}{c}\text { Meclodin } \\
\text { (5mg MCPH } \\
\text { / tablet) NDI-Iraq }\end{array}$ & 25 & 99.06 & 97.56 & 0.9 & 11.31 \\
\hline $\begin{array}{c}\text { Meclodin } \\
\text { (5mg MCPH } \\
\text { / tablet) }\end{array}$ & 25 & 99.36 & 97.96 & 0.6 & 5.59 \\
\hline $\begin{array}{c}\text { SDI-Iraq } \\
\text { MCPH } \\
\text { injection } \\
\left(\begin{array}{c}10 \text { mg/1ml }) \\
\text { Germany }\end{array}\right.\end{array}$ & 25 & 99.43 & 99.20 & 0.2 & 3.12 \\
\hline
\end{tabular}

* Average of three determinations.

\section{Comparison of the methods}

Table 10, shows the comparison between some of the analytical variables for the present method with that of other literature spectrophotometric methods. 
Table 10: Comparison of the methods.

\begin{tabular}{|c|c|c|c|c|}
\hline $\begin{array}{l}\text { Analytical } \\
\text { parameters }\end{array}$ & Present method & $\begin{array}{c}\text { Literature } \\
\text { method } \\
\text { (Amin and } \\
\text { Ragab, 2003) }\end{array}$ & $\begin{array}{c}\text { Literature } \\
\text { method (Khalil, } \\
\text { 2010) }\end{array}$ & $\begin{array}{c}\text { Literature } \\
\text { method (Al-Talib } \\
\text { and Mohammed, } \\
1996)\end{array}$ \\
\hline $\begin{array}{c}\text { Reaction } \\
\text { medium }\end{array}$ & Acidic & Acidic & Acidic & Acidic medium \\
\hline$\lambda \max (\mathrm{nm})$ & 654 & 510,522 & 500 & 612 \\
\hline Reagent & Arsenazo III & $\begin{array}{c}\text { o-phenanthroline } \\
\text {,bipyridyl }\end{array}$ & Pyrocatechol & Phenothiazine \\
\hline $\begin{array}{l}\text { Type of } \\
\text { method }\end{array}$ & $\begin{array}{l}\text { Oxidation- } \\
\text { reduction }\end{array}$ & $\begin{array}{l}\text { Oxidation- } \\
\text { reduction }\end{array}$ & $\begin{array}{l}\text { Oxidative } \\
\text { coupling }\end{array}$ & Oxidative coupling \\
\hline $\begin{array}{l}\text { Beer's law } \\
\text { range, ppm }\end{array}$ & $0.04-1.2$ & $\begin{array}{c}0.25-5.0 \\
0.2-5.8\end{array}$ & $5-35$ & $0.1-16$ \\
\hline $\begin{array}{c}\text { Molar } \\
\text { absorptivity } \\
\text { l.mol }{ }^{-1} . \mathrm{cm}^{-1}\end{array}$ & $9.36 \times 10^{4}$ & $\begin{array}{l}4.25 \times 10^{4}, \\
3.53 \times 10^{4}\end{array}$ & $3.01 \times 10^{3}$ & $1.65 \times 10^{4}$ \\
\hline $\begin{array}{l}\text { Application of } \\
\text { the method }\end{array}$ & $\begin{array}{c}\text { tablets and } \\
\text { injection }\end{array}$ & $\begin{array}{c}\text { tablets and } \\
\text { injection }\end{array}$ & $\begin{array}{l}\text { tablets, syrup and } \\
\text { drops }\end{array}$ & tablets \\
\hline
\end{tabular}

The results indicate that the proposed method has a good sensitivity and has a wide application part in determination of the drug under investigation in its pharmaceutical preparations.

\section{CONCLUSION}

The proposed method for the spectrophotometric determination of metoclopramidehydrochloride in pharmaceutical preparations is simple, sensitive, rapid, accurate and precise. The method is based on oxidation - reduction reaction between metoclopramide hydrochloride and cerium (IV) ion (ceric ion), then the subsequent reaction of cerium (III) with arsenazo III reagent in acidic medium to produce blue-violet complex which is stable, water soluble and has a maximum absorption at $654 \mathrm{~nm}$. the proposed method has been applied successfully to the determination of the intended compound in its pharmaceutical preparations (tablet and injection).

\section{REFERENCES}

Abdel-Gawad, F.M. ; El-Gunidi, N.M. (1995). Spectrophotometric determination of metoclopramide and oxybuprocaine through ion pair formation with thiocyanate and molybdenum (V) or cobalt (II), Anal. Lett., 28, 1437-1447.

Al-Arfaj, N. A. (2004). Flow-injection chemiluminescent determination of metoclopramide hydrochloride in pharmaceutical formulations and biological fluids using the $\left[\mathrm{Ru}(\mathrm{dipy})_{3}\right]^{2+}$ - permanganate system, Talanta, 62, 255. 
Al-Talib, S. M. ; Mohammed, S. A. (1996). Spectrophotometric assay of metoclopramide via oxidative coupling with phenothiazine and sodium metaperiodate, J. Edu. Sci., 18(4), 16-22.

Al-Ghabsha, T. S. ; Ahmed, R. A. ; Mahmood, H. Sh. (2004). Spectrophotometric study of some drugs using 2,3-dichloro-5-6-dicyano-p-benzoquinon (DDQ), J. Edu. Sci. , 16(4), 42-53.

Amin, A. S. ; Ragab, G. H. (2003). Spectrophotometric methods for the determination of anti-emetic drugs in bulk and in pharmaceutical preparations, Anal. Sci., 19, 747751.

Attia, M. S. ; Aboaly, M. M. (2010). Highly sensitive and selective spectrophotometric determination of metoclopramide hydrochloride in pharmaceutical tablets and serum samples using $\mathrm{Eu}^{3+}$ ion doped in sol-gel matrix, Talanta, 82(1), 78-84.

Avula, S. ; Babu, K. N. (2011). Development and validation of LC method for the analysis of metoclopramide in pharmaceutical dosage form and plasma, Intern. J. Res. Rev. Pharm. Appl. Sci., 1 (3), 104-117.

British Pharmacopoeia, Her Majesy's Stationary Office (2008). Cambridge, London, CDROM

Chang, Y. S. ; Ku, Y. R. ; Wen, K. C. ; Ho, L. K. (2000). Analysis of synthetic gastrointestinal drugs in adulterated traditional chines medicines by HPCE, J. Liq. Chromatogr. Relat. Technol. 23(13), 2009-2019.

Christian, G. D. (2004) ."Analytical Chemistry", 6th ed., John Wiley and Sons, Inc., New York, 90p.

Delevie, R. (1997). "Principles of Quantitative Chemical Analysis", Mcgraw-Hill, International Edition, Singapore, 498p.

Donnerer, J. (2003). "Antiemetic Therapy" , Basel , Karger, pp. 161-162.

Farghaly, O. A. ; Taher, M. A.; Naggar, A. H. ; El-Sayed, A. Y. (2005). Square wave anodic stripping voltammetric determination of metoclopramide in tablet and urine at carbon paste electrode, J. Pharm. Biomed. Anal. 38 (1), 14-20.

Faridbod, F. ; Ganjali, M. R. ; Labbafi, S. ; Dinarvand, R. ; Riahi, S. ; Norouzi, P. (2009). A New metoclopramide potentiometric membrane sensor for analysis in pharmaceutical formulation and urine, Int. J. Electrochem. Sci., $4,772-786$.

Hanna, G. M. ; Lau-Cam, C. A. (1991). H$^{1}$-NMR Spectroscopic assay method for metoclopramide hydrochloride in tablets and injections, Drug Dev. Ind. Pharm, 17 (7), 975-984.

Khalil, N. A. (2010). Determination of metoclopramide hydrochloride by spectrophotometric and HPLC methods - applications to pharmaceutical preparations, M.Sc. Thesis, University of Mosul, Iraq, pp. 33- 54.

Maquille, A. ; Jiwan, J. H. (2009). LC-MS characterization of metoclopramide photolysis products, J. Photochem. and Photobio. A: Chemistry 205, 197-202.

Moussa, B. A. (2000). Determination of some aminobenzoic acid derivatives glafenine and metoclopramide, J. Pharm. Biomed. Anal. , 23(6), 1045-1055.

Norouzi, P. ; Ganjali, M. R. ; Matloobi, P. (2005). Sub-second adsorption for subnanomolar monitoring of metoclopramide by fast stripping continuous cyclic voltammetry, Electrochem. Commun. 7(4), 333-338. 
Omran, A. A. (2005). Individual and simultaneous spectrophotometric determination of dapsone and metoclopramide - $\mathrm{HCl}$ in pharmaceutical dosage forms and synthetic binary mixtures, Chem. Pharm. Bull(Tokyo), 53(11), 1498-1501.

Patel, S. A. ; Patel, C. N. ; Patel, M. M. (2006). Visible spectrophotometric methods for the estimation of metoclopramide - $\mathrm{HCl}$ in tablets, Indian J. Pharm. Sci., 68(3), 397399.

Perrin, D. D. ; Dempsey, B. (1974) ." Buffer for pH and Metal Ion Control", Champman and Hall Ltd., London, pp. 131-135.

Revanasiddappa, H. D. ; Manju, B. (2001). A spectrophotometric method for the determination of metoclopramide hydrochloride and dapsone, J. Pharm. Biomed. Anal. , 25(3-4), 631-637.

Revanasiddappa, H. D. ; Veena, M. A. (2006). Sensitive spectrophotometric determination of metoclopramide hydrochloride and dapsone in bulk sample and dosage forms, Sci. Asia , 32, 319-321.

Sandell, E. B. ; Onishi, H. (1978). "Photometric Determination of Traces of Metals-Part 1" , 4th ed., John Wiley and Sons, New York, pp. 458-459,463-465.

Shah, J. ; Rasul, J. M. ; Azam, K. M. ; Amin, S. (2005). Spectrophotometric determination of metoclopramide in pharmaceutical preparations, Anal. Chem. , 60(7), 633-635.

Wang, Z. H. ; Zhang, H. Z. ; Zhou, S. P. ; Dong, W. J. (2001). Determination of trace metoclopramide by anodic stripping voltammetry with nafion modified glassy carbon electrode, Talanta, 53 (6), 1133-1138. 